\section{UNIVERSITY \\ OF DEBRECEN}

FACULTY OF

HEALTH

NYÍREGYHÁZA

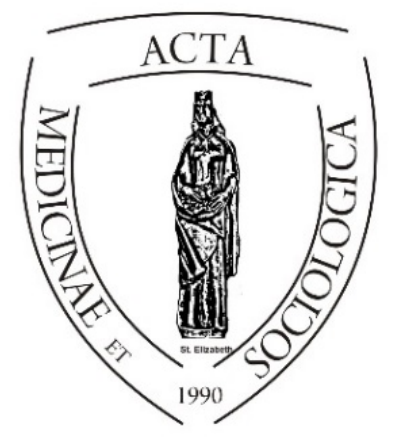

ACTA

MedSoc

VOLUME 6.

2015

\title{
Jövedelmi helyzet és jövedelmi szegénység
}

\section{Fábián Gergely - Takács Péter - Szigeti Fruzsina}

Tanulmányunkban a nyíregyházi háztartásokban és a Nyíregyházi járás területén keletkező és mérhető jövedelmek alakulását és azok eltéréseit vizsgáljuk. A jövedelmekhez kapcsolódóan definiáljuk és elemezzük a szegénységet is, így a relatív szegénységet, pontosabban a jövedelmi szegénységet vizsgáljuk, részben azért, mert ez köthető a legszorosabban a jövedelmi egyenlötlenségekhez, részben pedig azért, mert a szegénység más dimenzióit, úgymint anyagi depriváció, illetve lakhatási szegénység részletesen is elemzik a kötet más tanulmányai. ${ }^{21}$

A relatív, vagy más néven a jövedelmi szegénység alatt az Európai Unió Bizottsága által 2001-ben elfogadott, ún. Laekeni indikátorokat vettük alapul, amelyek alapján a szegénységi küszöb a medián ekvivalens jövedelem (nemzeti valutában mért) 60 százaléka. ${ }^{22}$

\footnotetext{
${ }^{21}$ A lakhatási szegénységgel is foglalkozik a kötetben Szoboszlai Katalin „Lakásjellemzők a Nyíregyházi járásban és a megyeszékhelyen" címü tanulmánya. Az anyagi depriváció részletes elemzését adja Szilicsány Éva Panna írása.

22 A medián ekvivalens jövedelem azt jelenti, hogy a felmért népességet az OECD 2 fogyasztási egységre jutó jövedelem alapján sorba rendezzük, melynek alapján a sor közepén lévő jövedelem jelenti a mediánt, amelyhez képest pontosan ugyanannyinak van kevesebb, illetve több jövedelme. Az OECD 2 fogyasztási egységkulcs azt jelenti, hogy a háztartás egyes tagjaihoz súlyokat rendelünk. Ez alapján az első felnőtt 1, minden további felnőtt 0,5, a 14 év alattiak pedig 0,3 egységet képviselnek. Bár az elfogadott indikátorok alapján a nemzetközi összehasonlítások is az OECD 2 skálát alkalmazzák, elterjedtek az egyéb számítási módok is (pl. az OECD 1 skála), amelyek némileg eltérő súlyokat alkalmaznak, közös jellemzöjük azonban mindig az, hogy kizárólag a jövedelmekre alapoznak. Tanulmányunkban bemutatjuk az alternatív módon számított adatokat is.
} 
Eddigi kutatási eredményeink alapján elmondható, hogy 2008 és 2010 között a város jövedelmi helyzetének jellemzői, illetve annak változásai számos esetben „lekövették” az országos tendenciákat. Bizonyos fokig kivételt képez ez alól a 2012es év, amikor is a városban mért szegénységi ráta csökkenést mutatott az előző évekhez képest, szemben az országos tendenciákkal, amelyek minden számítási mód szerint növekedést jeleztek. Ki kell azonban emelni, hogy a szegénység csökkenése ellenére a városban jelentősen nőttek a jövedelmi egyenlőtlenségek, jól mérhető társadalmi polarizálódás következett be.

2015-re „normalizálódott” a helyzet, azaz a várost nagyon hasonló tendenciák jellemezték, mint hazánkat, a változás pedig inkább tekinthető pozitívnak. A TÁRKI 2014-es Monitor Jelentése szerint Magyarországon 2010 és 2012 között jelentősen nőttek a jövedelmi egyenlőtlenségek, míg az elmúlt két évben az egy före jutó nettó jövedelmek jelentős növekedésének köszönhetően csökkentek, sőt, a csökkenés a legnagyobb mértékben annak köszönhető, hogy pozitív változások mérhetőek a jövedelem-eloszlás alján elhelyezkedő csoportok esetében, többek között nőtt a legalsó jövedelmi tized részesedése az összjövedelemből. A nettó jövedelmek abszolút értékben vett jelentős növekedése megjelent az alsó deciliseknél is. A legfelső decilis esetében hasonló változás mérhető, de a növekedés mértéke jóval kisebb, mint az alsó decilisek esetében (TÁRKI, 2015).

Gyakorlatilag ugyanez a változás következett be Nyíregyháza városában is, hiszen míg 2012-ben az egy före jutó átlagjövedelem 74 ezer forint volt, addig 2015ben már 85 ezer, ami közel 15 százalékos növekedést jelent. Ennél még kedvezőbben alakult a mediánjövedelem értéke, hiszen 66 ezer forintról 77 ezer forintra nőtt három év alatt. Igaz, a város elmaradása az országos értékektől még mindig jellemző, hiszen a 2014-re jellemző átlagjövedelem hazai értéke már megközelítette a 100 ezer forintot (Nyíregyháza Életminősége 2015).

A Nyíregyházi járás esetében már kedvezőtlenebb a kép, hiszen a járás településein mért átlagjövedelem 63345 forint volt, ami a Nyíregyházán mért 2008as jövedelmi helyzetnek felel meg (Nyíregyháza Életminősége 2015).

Az átlagjövedelem növekedése mindenképpen pozitívan értékelhető fejlemény, különösen, ha azt is figyelembe vesszük, hogy 2008 és 2012 között egy hazánkat is érintő gazdasági, financiális válság időszakát éltük. ${ }^{23}$

A jövedelmek vizsgálatánál az átlagérték egy igen jól használható mutató, különösen az időbeli és térbeni összehasonlítások tekintetében, mégis „,csalóka” lehet sok esetben, mivel elfed(het) olyan különbségeket, amelyek eröteljesen meghatározhatják a lakosok életminőségét. Ez a helyzet Nyíregyháza esetében is, ugyanis mind 2010-ben, mind 2012-ben a városra jellemzó átlagjövedelem alatt élt a lakosok 57 százaléka, ez a mutató gyakorlatilag változatlan, azaz 2015-ben is ez volt megfigyelhető, az alsó deciliseknél mért kedvezőbb helyzet ellenére is. Ez egyértelműen arra utal, hogy az alul és felül bekövetkezett növekedés hatására az egyenlőtlenség, azaz a csoportok közötti távolság nem csökkent jelentős mértékben.

\footnotetext{
${ }^{23}$ A vidéki Magyarország, a ,járadékos ország” helyzetét, és a komplex gazdasági válság hatásait igen részletesen elemzi Bódi Ferenc 2011-es tanulmánya.
} 
Ez az érték a Nyíregyházi járás esetében valamivel kedvezőbb, az ott mért átlagjövedelem alatt a lakosok 54 százaléka él.

1. táblázat: A jövedelmek egyenlötlenségei Nyíregyháza városában - az egy före jutó háztartási jövedelmek eloszlása a jövedelmi tizedek szerint, 2012-2015. (Átlagértékek, forintban)

\begin{tabular}{|l|c|c|c|}
\hline & 2012 & 2015 & $\%$ \\
\hline Alsó decilis & 22487 & 29057 & $+29,0$ \\
\hline 2. Decilis & 38359 & 43864 & $+14,0$ \\
\hline 3. Decilis & 48482 & 50835 & $+4,8$ \\
\hline 4. Decilis & 56787 & 62552 & $+10,0$ \\
\hline 5. Decilis & 63748 & 73173 & $+14,8$ \\
\hline 6. Decilis & 72450 & 81604 & $+12,6$ \\
\hline 7. Decilis & 81211 & 90697 & $+11,7$ \\
\hline 8. Decilis & 95185 & 100007 & $+1,0$ \\
\hline 9. Decilis & 113259 & 113571 & $+0,3$ \\
\hline Felső decilis & 174524 & 217818 & $+25,0$ \\
\hline S10/S1 & 7,7 & 7,5 & \\
\hline
\end{tabular}

(Forrás: Nyíregyháza Életminösége 2015)

Míg 2012-ben a két alsó decilis esetében csökkenés volt mérhető, addig 2015-re minden jövedelmi csoportra a növekedés jellemző. Kissé meglepő a 8. és 9. decilisek helyzete és a többi csoporthoz képest is alacsony növekedési aránya. Mivel a legerőteljesebb növekedés a legalsó és a legfelső csoportoknál következett be, így távolságuk (erre utal az S10/S1 mutató értéke) gyakorlatilag nem változott.

2. táblázat: A jövedelmek egyenlötlenségei Nyíregyházán és a Nyíregyházi járásban - az egy före jutó háztartási jövedelmek eloszlása a jövedelmi tizedek szerint, 2015. (Átlagértékek, forintban)

\begin{tabular}{|l|c|c|}
\hline & Nyíregyháza & Nyíregyházi járás \\
\hline Alsó decilis & 29057 & 17523 \\
\hline 2. Decilis & 43864 & 30514 \\
\hline 3. Decilis & 50835 & 37764 \\
\hline 4. Decilis & 62552 & 48152 \\
\hline 5. Decilis & 73173 & 54171 \\
\hline 6. Decilis & 81604 & 63739 \\
\hline 7. Decilis & 90697 & 72979 \\
\hline 8. Decilis & 100007 & 81961 \\
\hline 9. Decilis & 113571 & 94111 \\
\hline Felső decilis & 217818 & 130888 \\
\hline S10/S1 & 7,5 & 7,5 \\
\hline
\end{tabular}

(Forrás: Nyíregyháza Életminősége 2015)

Bár az S10/S1 mutató értéke azonos, az adatok jól tükrözik a város és a járás közötti igen jelentős különbségeket, amelyek minden csoportra jellemzőek. 
Mivel a jövedelmi egyenlőtlenségek egyik markáns magyarázója az iskolai végzettség, a város és a járás esetében mérhető, és igen jelentős eltérések állhatnak a különbségek hátterében.

3. táblázat: Iskolai végzettség Nyíregyházán és a Nyíregyházi járásban, 2015. (\%)

\begin{tabular}{|l|c|c|}
\hline & Nyíregyháza & Nyíregyháza Járás \\
\hline 8 általános alatt & 2,6 & 4,5 \\
\hline 8 általános & 8,4 & 22,4 \\
\hline Szakmunkásképző & 20,9 & 32,8 \\
\hline Szakközépiskola & 14,1 & 10,9 \\
\hline Gimnázium & 15,2 & 11,6 \\
\hline Technikum (érettségi utáni szakképzés) & 11,3 & 7,0 \\
\hline Főiskola & 19,6 & 9,4 \\
\hline Egyetem & 7,2 & 1,5 \\
\hline
\end{tabular}

(Forrás: Nyíregyháza Életminösége 2015)

Az eltérések alapvető jellemzője, hogy a járási lakosok körében jóval magasabb az alacsony iskolai végzettséggel rendelkezők aránya, és jóval alacsonyabb a magasan kvalifikált, azaz a diplomásoké. ${ }^{24}$

A korcsoportonkénti bontásban vizsgált eredmények is ezt a különbséget erősítik meg, hiszen a városban az érettségizettek, illetve a diplomások aránya jelentősen meghaladja a járáshoz tartozó településeken mérhető értékeket. ${ }^{25}$

A jól látható különbségek ellenére ez a differencia nem jelenik meg a foglalkoztatottságra vonatkozó adatokban, mivel Nyíregyházához képest a járáshoz tartozó településeken magasabb a 8 általános, illetve középfokú végzettséggel rendelkezők foglalkoztatottsága, és alacsonyabb a diplomásoké. ${ }^{26}$

Néhány település esetében még a városnál is kedvezőbb adatok figyelhetök meg, ugyanakkor Nyíregyháza kedvező helyzete ebben a dimenzióban is jól mérhető. ${ }^{27}$

Az eddig megismert jövedelmi adatokból kiindulva, azok pozitív tendenciái ellenére sem várható, hogy jelentősebb társadalmi átrendeződés ment volna végbe a

\footnotetext{
${ }^{24}$ Az elemzésből kihagytuk a doktori fokozattal rendelkezőket, az igen alacsony esetszám miatt.

${ }^{25}$ A részletes adatok megtalálhatók a kötetben Malakucziné Póka Mária tanulmányában.

${ }^{26}$ Ennek hátterében valószínüleg az eltérő gazdasági szerkezet és eltérő munkaerőpiaci viszonyok állnak.

27 A részletes adatokat tartalmazza a kötetben R. Fedor Anita és Balogh Erzsébet „A foglalkoztatás és a munkanélküliség jellemzői Nyíregyháza járásban” címü tanulmánya.
} 
városban. Ennek vizsgálatához érdemes áttekinteni az egyes társadalmi csoportok arányainak alakulását. $^{28}$

4. táblázat: Az egyes társadalmi csoportokhoz tartozók aránya Nyíregyháza városában, 2010-2015. (\%)

\begin{tabular}{|l|c|c|c|}
\hline & 2010 & 2012 & 2015 \\
\hline Jómódúak & 5,4 & 6,7 & 7,7 \\
\hline Felsö középréteg & 26,5 & 26,8 & 26,2 \\
\hline Középréteg & 29,1 & 33,4 & 32,7 \\
\hline Alsó középréteg & 27,6 & 22,7 & 23,8 \\
\hline Szegények & 11,4 & 10,5 & 9,5 \\
\hline
\end{tabular}

(Forrás: Nyíregyháza Életminősége 2015)

Az elmúlt öt évben nőtt a jómódban élök aránya, illetve folyamatosan csökkent a szegényeké. Utóbbi csoport esetében, a 2012 és 2015 közötti időszakot és az egy főre jutó jövedelmek növekedését figyelembe véve nem feltételezhető, hogy a szegénységből kilépők több csoportot ugrottak volna, ők inkább az alsó középréteget erősítik. Az viszont feltételezhető, hogy ugyanezen időszak alatt a középrétegből többen is képesek voltak korábbi helyzetükhöz képest jóval feljebb jutni, azaz ma már a jómódúakhoz tartoznak.

4. táblázat: Az egyes társadalmi csoportokhoz tartozók aránya Nyíregyházán és a Nyíregyházi járásban, 2015. (\%)

\begin{tabular}{|l|c|c|}
\hline & Nyíregyháza & Nyíregyházi járás \\
\hline Jómódúak & 7,7 & 8,8 \\
\hline Felső középréteg & 26,2 & 27,2 \\
\hline Középréteg & 32,7 & 30,6 \\
\hline Alsó középréteg & 23,8 & 19,0 \\
\hline Szegények & 9,5 & 14,3 \\
\hline
\end{tabular}

(Forrás: Nyíregyháza Életminösége 2015)

Markáns különbség figyelhető meg a szegénységben élők körében, hiszen a járásban jóval magasabb az arányuk. Bár a járásban magasabb a jómódúak aránya, kevesebben tartoznak a középréteghez, illetve az alsó középréteghez, ami arra utal, hogy a megyeszékhely „középosztályosabb” szerkezettel bír, mint a járás, amelyhez gazdasági-társadalmi szempontból heterogén összetételü települések tartoznak.

${ }^{28}$ Az egyes társadalmi csoportok besorolásánál a TÁRKI definícióit követtük, mely szerint „Jómódúak” (akiknek a medián kétszeresénél több a jövedelme), „Felsö-középréteg” (a medián 120-200 \%-a), „Középréteg” (a medián 80-120 \%-a), „Alsó középréteg” (a medián 50-80\%-a), ,Szegények” (50\% alatt). 
A városban mért, a jövedelmi egyenlőtlenségekre vonatkozó további mutatószámok alakulását mutatjuk be az alábbi táblázatban:

5. táblázat: A jövedelmi egyenlötlenségek egyes mutatóinak változása Nyíregyháza városában, 2008-2015.

\begin{tabular}{|c|c|c|c|c|}
\hline Mutatók & $\begin{array}{c}\text { Nyíregyháza, } \\
\mathbf{2 0 0 8}\end{array}$ & $\begin{array}{c}\text { Nyíregyháza, } \\
\mathbf{2 0 1 0}\end{array}$ & $\begin{array}{c}\text { Nyíregyháza, } \\
\mathbf{2 0 1 2}\end{array}$ & $\begin{array}{c}\text { Nyíregyháza, } \\
\mathbf{2 0 1 5}\end{array}$ \\
\hline $\mathrm{p} 10 / \mathrm{p} 50$ & 0,51 & 0,48 & 0,48 & 0,48 \\
\hline $\mathrm{p} 90 / \mathrm{p} 50$ & 1,68 & 1,7 & 1,8 & 1,7 \\
\hline $\mathrm{p} 90 / \mathrm{p} 10$ & 3,30 & 3,55 & 3,75 & 3,55 \\
\hline S10/S1 & 7,2 & 6,6 & 7,7 & 7,5 \\
\hline $\begin{array}{c}\text { Robin Hood } \\
\text { index }\end{array}$ & 20,0 & 20,0 & 20,0 & 20,0 \\
\hline $\begin{array}{c}\text { Éltető Frigyes } \\
\text { index }\end{array}$ & 2,21 & 2,25 & 2,26 & 2,27 \\
\hline GINI & 0,285 & 0,290 & 0,290 & 0,290 \\
\hline
\end{tabular}

2012-höz viszonyítva a helyzet alapvetően változatlan, az átlagjövedelmek növekedésének „szétterülése” meggátolta, hogy a jövedelmi olló tágabbra nyíljon, azaz növekedjenek az egyenlötlenségek. 2008-hoz viszonyítva ugyanakkor az egyenlötlenségek enyhe növekedése mérhetö, amelyre több adat is utal (ezek közül a GINI értékének, a p90/p10 mutatónak, de főleg az Éltető indexnek az alakulása a legfeltünőbb).

A járást hasonló adatok jellemzik, azzal a markáns különbséggel, hogy egyes mutatók a felsőbb társadalmi csoportok kedvezőbb, az alsóbb társadalmi csoportok kedvezőtlenebb helyzetére utalnak.

6. táblázat: A jövedelmi egyenlötlenségek mutatói Nyíregyháza városában és a Nyíregyházi járásban, 2015.

\begin{tabular}{|c|c|c|}
\hline Mutatók & Nyíregyháza & Nyíregyházi járás \\
\hline $\mathrm{p} 10 / \mathrm{p} 50$ & 0,48 & 0,43 \\
\hline $\mathrm{p} 90 / \mathrm{p} 50$ & 1,7 & 1,75 \\
\hline $\mathrm{p} 90 / \mathrm{p} 10$ & 3,55 & 4,0 \\
\hline S10/S1 & 7,5 & 7,5 \\
\hline Robin Hood index & 20,0 & 20,0 \\
\hline Éltető Frigyes index & 2,27 & 2,31 \\
\hline GINI & 0,290 & 0,280 \\
\hline
\end{tabular}


Különösen a p90/p10 mutató, illetve az Éltető index esetében látható különbség, ami arra utal, hogy a legfelső jövedelmi tized „távolabb áll” a társadalmi térben a legalsó jövedelmi tizedtől, mint a megyeszékhelyen. Mindenképpen kiemelendő, hogy a városban, még a gazdasági válság időszakában sem volt soha ennyire magas az Éltető index értéke.

A városban élő és az alsóbb társadalmi csoportokhoz tartozók 2010-hez és 2012höz képest kedvezőbb helyzetét mutatja az is, ha azt vizsgáljuk, hogy az egyes társadalmi csoportok milyen arányban részesednek az összjövedelemből.

7. táblázat: Az egyes társadalmi csoportok részesedése az összjövedelemböl, Nyíregyháza város, 2010-2015 (\%)

\begin{tabular}{|l|c|c|}
\hline & 2010 & 2015 \\
\hline Jómódúak & 15,0 & 12,2 \\
\hline Felső középréteg & 36,7 & 27,0 \\
\hline Középréteg & 27,7 & 30,5 \\
\hline Alsó középréteg & 17,3 & 21,4 \\
\hline Szegények & 3,8 & 5,3 \\
\hline
\end{tabular}

(Forrás: Nyíregyháza Életminösége 2015)

A szegények, illetve az alsó középosztály kedvezőbb helyzete kifejezetten pozitív elmozdulást jelez az elmúlt öt év vonatkozásában, amivel párhuzamosan csökkent a legtehetősebb csoportok részesedése, igaz a két legfelső csoport együttesen még mindig az összes jövedelem közel 40 százalékával bír. A megyeszékhely és a járás között ebben az esetben is markáns eltérések figyelhetők meg.

8. táblázat: Az egyes társadalmi csoportok részesedése az összjövedelemböl, Nyíregyháza város és Nyíregyházi járás, 2015 (\%)

\begin{tabular}{|l|c|c|}
\hline & Nyíregyháza & Nyíregyháza Járás \\
\hline Jómódúak & 12,2 & 18,7 \\
\hline Felső középréteg & 27,0 & 36,9 \\
\hline Középréteg & 30,5 & 28,3 \\
\hline Alsó középréteg & 21,4 & 11,2 \\
\hline Szegények & 5,3 & 4,7 \\
\hline
\end{tabular}

(Forrás: Nyíregyháza Életminösége 2015)

Míg a városban alacsonyabb a legtehetősebb csoportok részesedése az összes jövedelemből, addig a járásban mind a szegények, mind az alsó középréteg esetében kisebb arányok figyelhetők meg. A járásban a két felső csoport az összjövedelem 
55,6 százalékával rendelkezik. Ez a helyzet a Nyíregyházára jellemző három évvel ezelötti állapotot idézi.

A városban tapasztalt jövedelmi változások alapján feltételezhető, hogy csökkent a szegénységben élők aránya, szemben a korábbi folyamatokkal, hiszen a 2008 és 2010 közötti időszakra a növekedés volt jellemző. 2012-re enyhe csökkenést lehetett mérni, azzal, hogy a szegénységben élők aránya ekkor még mindig magasabb volt, mint 2008-ban.

9. táblázat: A szegénységre vonatkozó mutatók, Nyíregyháza 2010-2015.

\begin{tabular}{|l|c|c|c|}
\hline & $\mathbf{2 0 1 0}$ & $\mathbf{2 0 1 2}$ & $\mathbf{2 0 1 5}$ \\
\hline Egy före jutó jövedelem átlaga alapján & 14 & 13 & 13 \\
\hline OECD2 skála* & & & \\
\hline (OECD1 skála)** & 16,6 & & \\
\hline$(17,5)$ & 15,5 & & \\
\hline$(14,4)$ & 14,5 & & \\
\hline$(13,5)$ & & & \\
\hline Mediánjövedelem 50\% & 11,4 & 10,3 & 10,1 \\
\hline
\end{tabular}

(Forrás: Nyíregyháza Életminösége 2015)

*A szegénységi küszöb az OECD2 skála alapján számolva a mediánjövedelem 60 \%-a. (Skála: felnött 1, további felnött 0.5, gyermek 0.3 súlyú fogyasztási egység)

**A szegénységi küszöb az OECD1 skála alapján számolva a mediánjövedelem $60 \%$ \%-a.

(Skála: felnött 1, további felnött 0.7, gyermek 0.5 súlyú fogyasztási egység)

Míg az egy före jutó jövedelem átlaga, illetve a mediánjövedelem 50 százaléka mutatók esetében nem mérhető változás, addig a „hivatalosan” használt skálák esetében egy százalékos csökkenés tapasztalható 2012-höz képest. ${ }^{29}$ Általános tendencia, hogy 2010 óta folyamatosan csökken a szegénységben élők aránya a városban.

A városra jellemző 14,5 százalékos szegénységi ráta szinte teljesen megegyezik az EU-SILC által Magyarországra közölt adatokkal, ugyanakkor alacsonyabb értéket mutat a TÁRKI által mért 16,6 százalékos aránynál. ${ }^{30}$

A megyeszékhely és a járás települései közötti eltérések ebben az esetben is jellemzőek, hiszen a járás területén minden mutató esetében magasabb arányokkal találkozhatunk.

${ }^{29}$ A hivatalosnak tekinthető szegénységszámítások az egy före jutó mediánjövedelem 60 százalékánál „húzzák meg” a szegénységi határt, általában és leggyakrabban az OECD2 skála alkalmazásával. Az így definiált jövedelmi szegénység számítását alkalmazza nemzetközi tekintetben az Eurostat, hazánkban a Központi Statisztikai Hivatal, illetve a különböző kutatóintézetek.

${ }^{30}$ Az adatok forrása: KSH Stadat adatbázis, illetve EU-SILC adatbázis. 
10. táblázat: A szegénységre vonatkozó mutatók, Nyiregyháza és Nyíregyházi járás 2015.

\begin{tabular}{|l|c|c|}
\hline & Nyíregyháza & Nyíregyházi járás \\
\hline Egy före jutó jövedelem átlaga alapján & 13 & 17,9 \\
\hline OECD2 skála* & 14,5 & 22,0 \\
(OECD1 skála)** & $(13,5)$ & $(23,7)$ \\
\hline Mediánjövedelem $50 \%$ & 10,1 & 14,5 \\
\hline
\end{tabular}

A szegénység kiterjedtségét mutatja, hogy a járásban a szegények csoportját a három legalsó decilishez tartozók alkotják, Nyíregyháza városában ez a két legalsó decilisre korlátozódik. A járásra vonatkozó 22 százalékos érték soha nem volt jellemző a városban.

Érdekes kérdés, hogy az általunk vizsgált jellemzők hogyan és milyen mértékben befolyásolják a nyíregyházi lakosok életminőségét. Az életminőséget kutatási programunk 2010-es, második hullámában kidolgozott ún. FTI-index alkalmazásával mértük, amely 24 különbözö, az életminőség legfontosabb változóinak értékeit süríti egy indexbe. ${ }^{31}$

11. táblázat: Az FTI alapértékei a városban, 2008-2015.

\begin{tabular}{|c|c|c|c|c|}
\hline & 2008 & 2010 & 2012 & 2015 \\
\hline Átlag & 6,0 & 5,7 & 6,3 & 6,7 \\
\hline Sztenderdizált szórás & 4,5 & 4,2 & 4,4 & 4,1 \\
\hline Minimum érték & $-6,5$ & $-10,8$ & $-6,0$ & $-5,9$ \\
\hline Maximum érték & 21,1 & 18,7 & 19,2 & 22,2 \\
\hline
\end{tabular}

(Forrás: Nyíregyháza Életminösége 2015)

Az index növekedése, illetve egyes értékeinek változásai (pl. a szórás és a minimum érték csökkenése, a maximum növekedése) mindenképpen kedvezőnek mondható. Ebben a tekintetben is eltérő képet kapunk, ha az adatokat összevetjük a járásra jellemző értékekkel.

12. táblázat: Az FTI alapértékei a városban és a járásban, 2015.

\begin{tabular}{|c|c|c|}
\hline & Nyíregyháza & Nyíregyházi járás \\
\hline Átlag & 6,7 & 6,0 \\
\hline Sztenderdizált szórás & 4,1 & 4,4 \\
\hline Minimum érték & $-5,9$ & $-6,7$ \\
\hline Maximum érték & 22,2 & 24,8 \\
\hline
\end{tabular}

(Forrás: Nyíregyháza Életminösége 2015)

${ }^{31}$ Az index kialakításának módszertani leírását tartalmazza az „Életminőség Nyíregyházán” címü kötetben 2012-ben megjelent írásunk. Az index negatív és pozitív értéket is felvehet, a negatív érték rossz életminőséget, míg a pozitív jó életkörülményeket, életminőséget jelent. 
A járásra jellemző FTI értékek eltérése is a jelentősebb társadalmi különbségekre utalnak, amelyek azonban nemcsak a jövedelmek területén mérhetőek, hanem az életminőség szempontjából is. Ezt az eredményt erősíti meg az is, ha az eltéréseket a különböző társadalmi csoportok függvényében vizsgáljuk.

13. táblázat: Az FTI átlagértéke a városban és a járásban az egyes társadalmi csoportok körében, 2015.

\begin{tabular}{|c|c|c|}
\hline & Nyíregyháza & Nyíregyházi járás \\
\hline Jómódúak & 9,4 & 10,9 \\
\hline Felsö középréteg & 6,4 & 5,7 \\
\hline Középréteg & 5,6 & 6,7 \\
\hline Alsó középréteg & 6,4 & 4,2 \\
\hline Szegények & 5,8 & 3,9 \\
\hline
\end{tabular}

(Forrás: Nyíregyháza Életminősége 2015)

Különösen „felül és alul” láthatóak markáns eltérések a város és a járás között, azzal, hogy elsősorban a szegények és az alsó középréteghez tartozók tekinthetők hátrányos helyzetüeknek. A város esetében érdemes azt is áttekinteni, hogyan alakultak az index értékei az elmúlt években.

14. táblázat: Az FTI átlagértékeinek alakulása Nyíregyházán az egyes társadalmi csoportok körében, 2008-2015.

\begin{tabular}{|c|c|c|c|c|}
\hline & 2008 & 2010 & 2012 & 2015 \\
\hline Jómódúak & 9,4 & 7,8 & 8,5 & 9,4 \\
\hline Felsö középréteg & 6,5 & 7,0 & 6,8 & 6,4 \\
\hline Középréteg & 5,7 & 5,2 & 5,8 & 5,6 \\
\hline Alsó középréteg & 5,4 & 5,3 & 5,7 & 6,4 \\
\hline Szegények & 4,5 & 3,5 & 4,9 & 5,8 \\
\hline
\end{tabular}

(Forrás: Nyíregyháza Életminösége 2015)

Általános tendenciaként fogalmazható meg, hogy a gazdasági válság időszakában csökkent a nyíregyházi lakosok életminősége, 2010 óta kedvezőbb a helyzet, igaz, több csoport esetében 2015-re érte el csak a mutató a válság elötti szintet. Mindenképpen kedvezö fejlemény, hogy az alsó középrétegre és a szegényekre vonatkozó indexérték 2015-ben magasabb volt, nemcsak 2012-höz képest, hanem 2008-hoz képest is.

\section{Összegzés}

Nyíregyháza városában a gazdasági-társadalmi válság hatásai 2008 és 2010 között voltak a legeröteljesebbek, csökkent a foglalkoztatottság, nőtt a munkanélküliek száma, és nőtt a szegénységben élők aránya is. Általánosságban is jól mérhető volt a jövedelmek csökkenése ebben az időszakban. 2008 és 2010 között jelentősen romlottak az általunk kidolgozott életminőség index értékei is.

A 2010 és 2012 közötti periódus a válságból való kilábalás időszaka volt, nőtt a foglalkoztatottak aránya, nominális értékben is nőttek a jövedelmek (a növekedés 
mind a háztartásokra jutó összjövedelem, mind az egy före jutó jövedelmek esetében mérhető volt), a szegénységben élők aránya is enyhe csökkenést mutatott, és az FTI értékei is kedvezőbbek lettek.

A kedvező tendenciák folytatódtak 2012 és 2015 között is, nőttek a nettó jövedelmek, a növekedés pedig nemcsak „szétterült” a város társadalmi terében, hanem jelentős emelkedést mutatott a legalsó decilis esetében. Igaz ez a változás a legfelső decilis esetében is bekövetkezett, amelynek eredményeképpen az egyes csoportok távolsága nem változott, azaz a már korábban mért jövedelmi egyenlőtlenségek továbbra is jellemzik a várost. Kedvező változás, hogy 2012-höz képest újabb 1 százalékkal csökkent a szegénységben élők aránya, illetve, hogy nőtt az FTI-index értéke is.

A megyeszékhely és a járás települései között markáns eltérések figyelhetők meg, alapvetően a Nyíregyházi járás kárára. Esetükben jelentősebb különbségek mérhetőek, a szegénységben élők aránya is jóval magasabb, mint a városban. A szegénység alapvetően a három alsó decilist jelenti, szemben a megyeszékhellyel, ahol ez a két alsó decilisre korlátozódik. Nyíregyházához képest az életminőséget mérő index különböző értékei is jelentősebb eltéréseket mutatnak.

Ezek az eredmények szintén azt a jelenséget támasztják alá, amely alapján a megyeszékhely egyfajta szigetszerü fejlődést mutat, hiszen szinte minden tekintetben kedvezőbb adatokkal rendelkezik, mint a megye, vagy éppen a járás. Ez alól legfeljebb azok a kisebb települések jelentenek kivételt, amelyek közvetlenül Nyíregyháza mellett találhatók (ilyen pl. Nyírpazony), ezek azonban a városi agglomeráció települései. A megyeszékhely dinamikus fejlődése már évek óta jellemző folyamat, ez a fejlődés azonban már kevésbé igaz a járásra, vagy éppen a megyére. A nagy kérdés az, hogy mennyire képes a város „magával húzni” a járáshoz tartozó településeket, azaz mekkora a földrajzi hatósugara a megyeszékhelyet jellemző fejlődésnek.

Ennek tükrében elsősorban a járáshoz tartozó településeken kell kidolgozni olyan lokális, illetve regionális programokat, amelyek javíthatják a lakosok gazdaságitársadalmi helyzetét, végső soron az ott lakók életminőségét. ${ }^{32}$

\section{Irodalom}

Bódi Ferenc (2011): A komplex válság elemei és hatása a vidéki társadalmakra. In: Bódi Ferenc-Fábián Gergely (szerk): Helyi szociális ellátórendszer Magyarországon. Debrecen University Press, Debrecen. 113-127.

Fónai Mihály (2011): A települési problémák és a lakossági szükségletek lehetséges hatása a helyi politikára. In: Bódi Ferenc-Fábián Gergely (szerk): Helyi szociális ellátórendszer Magyarországon. Debrecen University Press, Debrecen. 127.

Malakucziné Póka Mária (2015): A Nyíregyházai járás települési szerkezeti, demográfiai, háztartási jellemzöi. Acta Medicinae et Sociologica Vol. 6. No. 18-19. 11-29

32 Tanulmányunkban nem térünk ki a helyi szociálpolitika lehetséges feladataira, válaszlehetőségeire, ugyanakkor az olvasó figyelmébe ajánljuk Fónai Mihály 2011-es írását, amelyben a szerző részletesen is elemzi a települési problémák, a lakossági szükségletek és a helyi politika összefüggéseit. 
R. Fedor Anita-Balogh Erzsébet (2015): A foglalkoztatás és a munkanélküliség jellemzői a Nyíregyházi járásban. Acta Medicinae et Sociologica Vol. 6. No. 18-19. 47-67

Szilicsány Éva Panna (2015): Acta Medicinae et Sociologica Vol. 6. No. 18-19. 80-95

Szoboszlai Katalin (2015): Lakásjellemzők a Nyíregyházi járásban és a megyeszékhelyen. Acta Medicinae et Sociologica Vol. 6. No. 18-19. 30-46

Takács Péter-Fábián Gergely (2012): Egy lokális életminőség index kialakításának lépései. In: Fábián Gergely-Patyán László-Huszti Éva (szerk): Életminőség Nyíregyházán, 2008-2010. Debreceni Egyetem Egészségügyi Kar, Nyíregyháza. 49-69.

TÁRKI (2015): Jól nézünk ki (...?!). Háztartások helyzete a válság után. Szerk.: Szívós Péter-Tóth István György. Budapest.

\section{Melléklet}

\section{A jövedelmi egyenlőttlenségekre vonatkozó mutatók:}

$\mathbf{p 1 0} / \mathbf{p 5 0}=$ a mutatószám az alsó jövedelmi tized felső határpontját viszonyítja a mediánhoz.

p90/p50 = a mutatószám a legfelső jövedelmi tized alsó határát viszonyítja a mediánhoz.

p90/p10 = a mutatószám az alsó jövedelmi tized felső határpontját viszonyítja a felső jövedelmi tized alsó határpontjához.

$\mathbf{S 1 0 / S 1}=$ a legalsó decilis és a legfelső decilis átlagjövedelmének hányadosa, azaz hányszorosa a legfelső decilis átlagjövedelme a legalsónak.

Robin Hood index = az egyenlőtlenségek általános szintjének kimutatására szolgál. Kiindulópontja, hogy teljes egyenlőség esetén a jövedelmek egyenletesen oszlanak meg az egyének között, azaz mindegyik jövedelmi tizedbe a népesség összjövedelmének 10-10 százaléka esik. A Robin Hood-index ettől az egyenletes megoszlástól való eltérést mutatja: a 10 százaléknál nagyobb jövedelemaránnyal rendelkező decilisek 10 százalék feletti százalékrészeinek összegeként számolható ki. Másként megfogalmazva, ha akadna egy Robin Hood, aki a gazdagoktól elvett javakat a szegények számára szeretné újraosztani, akkor a szóban forgó index azt jelentené, hogy maximum mekkora hányadot kellene átcsoportosítani, hogy kiegyenlítődjenek a jövedelmi egyenlőtlenségek.

Éltető Frigyes index: az átlag feletti és az átlag alatti jövedelmek hányadosa, azaz az átlag fölötti jövedelmek átlagát az átlag alatti jövedelmek átlagával vetjük össze. Teljes jövedelemegyenlöség esetén a mutató értéke 1, ennél nagyobb érték a jövedelmi olló nagyságát mutatja.

GINI $=$ az egyenlőtlenség olyan mértékegysége, amely 0 és 1 között vehet fel értékeket. $0=$ teljes egyenlőség, $1=$ teljes egyenlőtlenség, azaz egy ember rendelkezik az összes jövedelemmel. A Gini-index azt méri, hogy egy adott országban, településen, stb. a jövedelmek eloszlása mennyiben tér el az abszolút egyenlöségtől.

\section{Szerző(k):}

Fábián Gergely Ph.D.: szociológus, főiskolai tanár

Debreceni Egyetem Egészségügyi Kar, 4400 Nyíregyháza, Sóstói u. 2-4. 